\title{
The Effect of Selection Factors of Marine Transportation Service on Transaction Continuity
}

\author{
Beom-Soo KIM ${ }^{1}$, Bo-Young KIM ${ }^{2}$ \\ Received: October 31, 2019 Revised: November 15, 2019 Accepted: November 20, 2019
}

\begin{abstract}
The selection factors of service companies have changed in accordance with intensifying competition in the marine transportation service market and environment changes of transportation services. To explore the important factors of customer choice to marine transportation service, this study empirically examines the influence of these selection factors; service provision area, price competitiveness, corporate image, service expertise, and sales support, on transaction continuity through customers' perceived service value and satisfaction. Based on an online survey with those in the Korean marine transportation industry, this study conducted statistical analyses using structural equation modeling. Based on relevant previous studies, the current study constructed a total of 55 survey questions. Finally, 213 questionnaires were collected. Among the five selection factors, corporate image did not affect perceived service value, and price competitiveness was still the most important factor. However, service expertise and sales support were found to be more important factors than regional factors. In order to maintain transaction continuity, shipping companies should also strive to improve their service quality to their customers. In particular, service quality strategies focused on time and regional factors should develop to strategies with the key factors for the changed business environment.
\end{abstract}

Keywords : Marine Transportation, Service Provision, Price Competitiveness, Service Value, Customer Satisfaction

JEL Classification Code : M10, M12, L200, O16

\section{Introduction}

According to the 2019 Marine Transportation Outlook report, due to the decrease in economic growth, world trade growth is expected to drop to $4.2 \%$, down by $0.9 \%$ from 2018 (Korea Maritime Institute, 2018). As such, examining changes in the marine transportation market over the past decade, the growth trend in cargo volume is slowing as global economic growth continues to decline, excluding certain regions like the U.S. Conversely, there is an oversupply of vessels in the marine transportation market due to the extensive input of ultra-large vessels ordered

1 First Author, PhD Candidate, Seoul Business School, aSSIST, South Korea.Email: bsk623@naver.com

2 Corresponding Author, Associate Professor, Seoul Business School, aSSIST, South Korea. [Postal Address: 46 Ewhayeodae2-gil, Seodaemun-gu, Seoul, 03767 Korea] Email: bykim2@assist.ac.kr

(c) Copyright: Korean Distribution Science Association (KODISA)

This is an Open Access article distributed under the terms of the Creative Commons Attribution Non-Commercial License (http://Creativecommons.org/licenses/by-nc/4.0/) which permits unrestricted noncommercial use, distribution, and reproduction in any medium, provided the original work is properly cited. during the economic boom (Drewry Maritime Research, 2018). Further, new types of competition and cooperation are forming in the marine transportation market, including cooperation between independent shipbuilders seeking economies of scale through large mergers and acquisitions and alliances against them (Panayides \& Wiedmer, 2011). In particular, independent shipbuilders and alliances with large fleets are pursuing aggressive business strategies to secure market share to match their scale, with a focus on securing a differentiated competitive advantage strategy (Kim et al., 2009).

Marine transportation is a transport service; in this regard, the characteristics of transport services partially differ from general services. When examined from a marketing perspective, the marine transportation service has characteristics similar to those of a service industry. This is because marine transportation is a pure service that serves as the main service for a few products. Moreover, in terms of demand characteristics, both production and consumption occur simultaneously in marine transportation services, preventing storage and inventory management. Thus, from a 
performance-oriented perspective, marine transportation services do not require customers to participate directly in the production and consumption of services. Rather, the successful transportation of cargo as per the contract becomes the customer's concern and a measure for evaluating the service. In addition, in marine transportation services, demand preparation should always be made assuming full load. This therefore characterizes the aspect of capacity cost, a principal cost of basic production. In particular, competition for price leadership in marine transportation services occurs due to changes in supply and demand conditions, and in the liner and tramper markets, there is a dynamic relationship between service providers and consumers (Lee et al., 2010).

Tan and Wisner (2000) reported that internal factors of numerous industries, particularly transportation, include the role and leadership of the CEO, human resource management, information management systems, equipment management, and operations. He also argued that external factors include service to customers, maintaining strategic relationships with customers and suppliers, and promoting benchmarking within and outside the company. Finally, he claimed that marine transportation companies should differentiate their services by strategically improving service quality and developing new services. With regards to liner marine transportation companies, Frankel (1992) introduced nine factors that shippers have in common, consisting of service reliability, compliance with transit time and delivery time, availability of promised or published transit capacity, cargo safety, cargo movement management and tracking, validity of documents and information distribution, cost control and management, settlement work, service status, and future planning, which form complex transport management. In addition, Shin et al. (2015) explained that rapid processing and cargo damage prevention, convenience of sales, and overall corporate image could be important competitive factors in transportation services. Thus, in order to respond to rapid logistics changes, marine transportation companies must strive to differentiate and enhance their marine transportation services to obtain a competitive advantage (Hwang \& Goo, 2015).

Accordingly, this study classified selection factors influencing the use of transportation services of marine transportation companies into 'service provision area', 'corporate image', 'price competitiveness', 'service expertise', and 'sales support', and then empirically examined the influence of these selection factors on transaction continuity through customers' perceived service value and satisfaction. In line with changing circumstances of the marine transportation industry and changing service needs, this study identifies which service factors are important for customers when using services in the marine transportation service market. Through this, the study seeks to provide specific implications on how marine transportation companies should devise their service strategies to become competitive in the global market.

\section{Theoretical Background and Hypothesis}

\subsection{Understanding Marine Transportation Service}

Service in the marine transportation industry can be seen as a human economic activity that creates spatial movement of humans or cargo through transportation services, in which physical facilities of ships and human labour force combine to move certain quantities of objects to certain distances. As such, marine transportation service is defined as the combination of physical facilities, such as ships and human labour, to create the utility of freight transportation (Durvasula et al., 2000; Shirley et al., 1993). Marine transportation companies that provide these services enter into management contracts with ship owners and perform some or all of the ship management functions on behalf of ship owners. Moreover, such enterprises are defined as expert service companies that provide various special services to ship owners and receive management fees from them (Baek \& Kwon, 2012). Marine transportation services essentially consist of a logistics service, which is the activity of connecting the departure point to the destination through transportation routes. Among logistics functions including packaging, unloading, storage, transportation, and information, this is mainly responsible for transportation (Kim \& Joo, 2008; Lai, 2004). Recently, other logistics functions have also been integrated into the area of marine transportation services. This should break away from the narrow, conventional concept of "transporting people or cargo using ships at sea and receiving a fee in return", which is a concept of marine transportation, and include certain areas of logistics services to form a broader concept of marine transportation services.

Marine transportation service is a service based on equipment with limited customer contact and little dependence on humans in the production of the service. As such, when dividing services into people-based and equipment-based services, marine transportation is classified as a low labour-intensive service industry; thus, it is capitalintensive. Marine transportation service is also affected by the demand for international trade activities as a derived demand. That is, it is one of the derived demands generated by the fundamental demand of trade. Accordingly, when examining demand for marine transportation services, one should analyze not only international trade activities but also activities of production and distribution of the economy. Consequently, marine transportation demand is impacted by not only transportation costs but also price differences between the origin and destination, tariffs imposed on imported goods, and other facets of demand elasticity. Conversely, as marine transportation is a capital-intensive industry, it has the industrial characteristic in which it is difficult to control output in response to changes in demand. Further, as marine transportation services have very low transportation costs compared to land and air transportation, 
price changes in alternative transportation services have little effect on the demand for marine transportation services (Kim, 2016; Durvasula et al., 2000).

In addition, transportation of large quantities is possible, and the freedom of transportation routes and diversity of transportation destinations serve as positive characteristics in marine transportation services. Marine transportation has the capacity to transport up to hundreds of thousands of tons of single cargo at a time, enabling transportation of large quantities as compared to other means of transportation. Moreover, the cost of transportation per unit is low owing to economies of scale. Marine transportation has greater freedom of transport compared to other transport services such as railways, trucks, pipelines, aviation, and the like limited to rails, road, pipeline facilities, and restricted transport routes. Moreover, nearly all types of goods can be shipped, including cargo, packaged units, and liquids and it is unaffected by physical attributes such as solids. As a result, while marine transportation is slow, it has grown by being able to transport large quantities over long distances and due to low cost (Peason, 1980; Lee, 2014).

The marine transportation industry, which is divided into liner, tramper, and tanker ship markets, has the characteristics of basic market mechanisms by sector. As such, the quality of marine transportation services is also inevitably heterogeneous and highly multifaceted. Nevertheless, no clear concept of marine transportation service quality has been established. This is because the contents of marine transportation services have so far been limited to the maritime sector defined according to technical characteristics of ships. This prevents differentiation among products or services, thus leading competitive factors of shipping companies to depend on price. In case of liner marine transportation, in the multimodal transport system, which was introduced as a new logistics system in which certain freight agreements are made, the service quality of the shipping company becomes an important selection factor of the shipper. Unlike maritime sector services, which consist of hardware such as ships and terminals, liner marine transportation consists of quality factors that cannot easily be bested by other ships. Accordingly, quality control in these fields is directly related to the company's competitiveness.

\subsection{Selection Factors and Perceived Service Value}

Numerous previous studies have introduced competitive factors that influence the business success of marine transportation companies. Lai (2004) suggested that logistics service companies' EDI linkage, freight tracking, customer response, service reliability, and value-added service capabilities affect the marine transportation companies' success. Panayides and Wiedmer (2011) found that integration of port and terminal information, the relationship with liner shipping companies, and value-added service capabilities positively affect company performance. Yang et al. (2009) suggested resources, logistics service capabilities, and innovation capabilities of container marine transportation service companies. The common important factor mentioned in these studies is price competitiveness. Drewry Maritime Research (2018) reported that logistics costs had the most significant effect on competitiveness in the marine transportation industry, and Cha and Seo (2019) also argued that observable services that impact the costs of marine transportation companies as well as shippers are important. The regional factor is also considered important in transportation services in the marine transportation industry. Rahman (2018) categorized the container terminal service quality dimensions into internal environmental quality, the terminal's own capability, and external environmental quality, which affects the container terminal, and argued that the location of the terminal acts as an important selection factor. Further, Tabash et al. (2019) explained that regional accessibility has a significant effect on the use of marine transportation services.

In addition, Desarbo et al. (2001) described that shippers are service-oriented and that the process of shippers selecting carriers is a process of transaction. He explained that the low cost of logistics is a determinant under the premise that shippers' interests are homogeneous, thus emphasizing the importance of service orientation. Cronin et al. (2000) argued that the quality of transportation services, such as average transport time, transit time, and shipment size, has a significant effect on the resource consumption of both marine transportation companies and shippers in large distribution processes, thus exerting a large economic impact. Meanwhile, Dwyer and Oh (1987), explained that the quality of marine transportation services directly influences customer satisfaction and loyalty.

Additionally, previous studies on factors influencing the selection of the transportation services of marine transportation companies include the following. As selection factors, Chane et al. (2011) suggested the following in terms of production: frequency of cargo damage, ship capacity, delay of transshipment, and frequency and uncertainty of service; and in terms of transactions, clarity of service type, supplier accessibility, ease of negotiation, insurance status, and reliability of contract performance. Kinard and Capella (2006) presented factors of service quality, convenience of sales, flexibility and dependence, contribution to service promotion, and overall image. Culnan and Bies (2003), emphasized service expertise, efficiency, and active sales support for customers, while Kinard and Capella (2006) emphasized communication. Chellappa and Sin (2005) suggested the partner relationship between port service companies, while Lee (2014) stated that information services are important. Factors influencing these selections ultimately impact the perceived quality of service of customers, in which the perceived value is the individual's recognition and evaluation of the superiority or excellence of a product or service (Zeithaml, 1988). Value is the feeling of a person's subjective needs and desires related to the use 
or consumption of a particular product or service attribute. As this refers to subjective rewards or expectations that an individual desires through the use of the product or service, the greater the impact on the choice to use the service, the higher perceived service value (Bolton \& Drew, 1991).

As the attributes of the product benefit the consumer, Aaker and Day (1986) referred to attributes as beneficial values and classified them as rational and psychological. Rational values are associated with objective and physical attributes of the product and are known to impact individual decision-making; in contrast, psychological benefits associated with subjective and personal attributes are known to impact the process of attitude formation. Thus, when an individual purchases a product or service, the individual purchases the value that the product's attributes provide rather than the attributes themselves, thus satisfying the individual's desires or needs (Taylor \& Baker, 1994).

Marine cargo transportation services are concerned with numerous factors, including the safety and speed of the customer's cargo and the reliability of the carrier. Therefore, according to the expectancy-disconfirmation paradigm, which regards the value of marine transportation service as the difference between the customer's expectation and the perceived performance, the factor for selecting the service can be determined by the degree of inconsistency between the perceived value of the shipper's services to the marine transportation company (Lee et al., 2010). Accordingly, as presented in previous studies (Kinard \& Capella, 2006; Peter \& Olson, 1994; Julian, 1999; Dick \& Basu, 1994; Ganesh et al., 2000), customers' perceived value of services such as timeliness, service efficiency or suitability, safety based on security or trust, and value can relate to the selection factors for marine transportation services.

As such, to support the argument that selection factors of transportation services by marine transportation companies have an effect on perceived service value, this study establishes the following hypotheses and verifies their relationships.

Hypothesis 1: Among the transportation service use selection factors of marine transportation companies, service provision area will have a positive effect on perceived service value.

Hypothesis 2: Among the transportation service use selection factors of marine transportation companies, corporate image will have a positive effect on perceived service value.

Hypothesis 3: Among the transportation service use selection factors of marine transportation companies, price competitiveness will have a positive effect on perceived service value.

Hypothesis 4: Among the transportation service use selection factors of marine transportation companies, service expertise will have a positive effect on perceived service value.

Hypothesis 5: Among the transportation service use selection factors of marine transportation companies, sales support will have a positive effect on perceived service value.

\subsection{Perceived Service Value, Service Satisfaction, and Transaction Continuity}

The customer's perceived value is a key concept in marketing; companies can secure competitive advantages by providing high-value products and services demanded by customers (Woodruff, 1997). This is derived from personal experiences, products, services, and interactions (Turel et al, 2010). Researchers have long considered understanding the value of a product or service from the user's perspective as a successful customer strategy (Desarbo et al, 2001). Previous research related to this customer perception has defined the usefulness of a product or service, which is determined by the perception of what a customer receives or is given as the overall evaluation of the consumer (Pearson, 1980). It has also been defined in simple terms, such as the quality of goods or services or the trade-off in prices (Rahman, 2018).

Previous studies have noted that value should be considered to enable specific actions for practical and pleasure purposes (Chiu et al., 2012; Kim et al., 2009). However, as customers' final perceived value of goods and services results from a consideration of various factors, researchers have argued that price and quality alone are insufficient to comprehensively assess the value perceived by customers (Sweeney \& Soutar, 2001). As such, researchers are attempting to conceptualize customer perceived value in a more multidimensional structure, and its definition is becoming increasingly fragmented ( $\mathrm{Ju}$, 2007). Komiak and Benbasat (2006) explained that consumer satisfaction with a service depends on the level of the consumer's expectations, and that satisfaction depends on the perceived level of service provided. Gwinner et al. (1998) defined "customer's perceived level of expectation of the delivered service" as perceived service value.

Examining various studies on marine transportation services, the perceived service quality or value of the customer impacts their service satisfaction or transaction continuity. (Gundlach et al. 1995; Morgan \& Hunt 1994; Sun et al., 2005). In a related study on marine transportation services, Ahn et al. (2008) investigated whether the value of container port service quality has a differentiated affecting on service satisfaction, reuse, and word-of-mouth intention. As a result, they identified and divided the container port service quality dimensions into internal quality, external environmental quality, and interaction quality. Kim et al. (2007) pointed out that the effect on service satisfaction and loyalty were positive when the customer's expectations of tangibility, reliability, and confidence in marine 
transportation services were satisfied (Kuo et al. 2009). Moreover, as indicated by Kinard and Capella (2006) service satisfaction leads to repeat purchases and transaction continuity. Numerous studies (Kollat et al., 1970; Peter \& Olson; 1994; Komiak \& Benbasat, 2006; Taylor \& Baker, 1994; Reichheld, 1993) have already defined customer satisfaction with services as a result that can create transaction continuity for repeat product and service purchases.

Consequently, the higher the service satisfaction of customers in port services, the more likely the transaction continuity. Based on previous empirical studies related to service satisfaction and transaction continuity of various port services (Cha \& Seo, 2019; Kim \& Ju, 2008). This study also established the following hypotheses that marine transportation company customers' perceived service value of transportation services affects their service satisfaction, and that service satisfaction has a positive effect on transaction continuity.

Hypothesis 6: The perceived service value of the transportation services of marine transportation companies will have a positive effect on service satisfaction.

Hypothesis 7: Satisfaction with marine transportation services provided by marine transportation companies will have a positive effect on transaction continuity.

\section{Methodology}

\subsection{Research Model}

This study sought to empirically analyze the influence of marine transportation service use selection factors that improve transaction continuity through the perceived service value and satisfaction of marine transportation services. The transportation service selection factors in the marine transportation industry can be defined as 'service provision area', 'corporate image', 'price competitiveness', 'service expertise', and 'sales support'. As perceived service value and satisfaction increase in accordance with these five factors, transactions for transportation services can continue. Accordingly, this relationship was designed as a research model constructed on the hypotheses based on preceding research, as presented in Figure 1. As independent variables, the five selection factors of service provision area, corporate image, price competitiveness, service expertise, and sales support were used. Perceived service value and service satisfaction were defined as parameters, and transaction continuity was defined as the dependent variable. Path analyses were performed for each relationship based on structural equation modelling, after which the mediating effect on perceived service value and service satisfaction were verified.

\section{Selection Factors of Marine \\ Transportation Logistics Service}

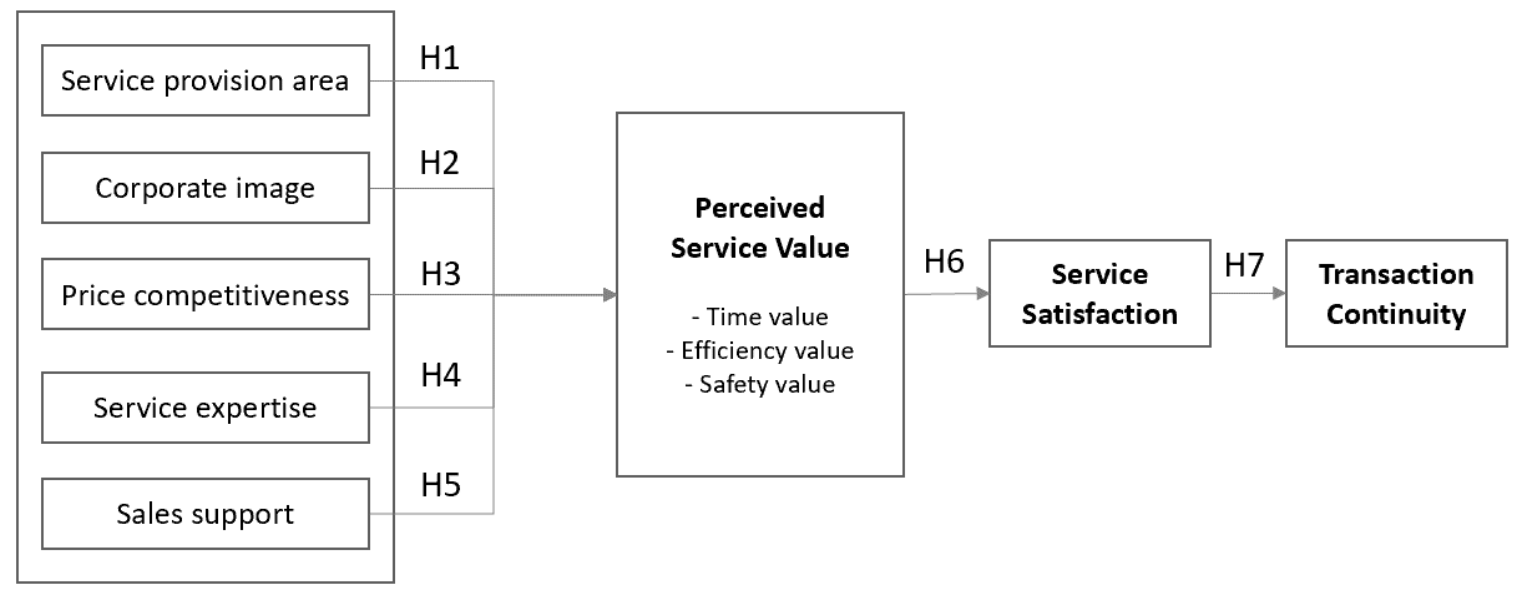

Figure 1: Research Model

\subsection{Measurement Variable and Data Collection}

This study conducted a survey to collect the data needed to analyze this model. To construct the survey, the items presented in Table 1 were used based on previous studies, and operational variables of the survey components were defined. Examining the operational definitions of the variables used for the survey, 'marine transportation service use selection factor' refers to service activities including the service area provided by the marine transportation company to the customer, freight, schedule, and sales support staff. These were classified into five areas: service provision area, corporate image, price competitiveness, service expertise, and sales support. 'service provision area' refers to regional factors including place of shipment, unloading ports, destinations and the like, provided by the marine 
transportation company to customers. 'corporate image' refers to the reliability and service reputation of marine transportation companies that customers consider when selecting a marine transportation company. 'price competitiveness' refers to the factors of price benefits and relative freight levels for services and accurate freight proposals. 'service expertise' refers to factors related to marine transportation service expertise, including accurate schedules, timely arrival and departure, and appropriate transport handling capacity. 'sales support' refers to factors such as knowledge level, information power, and work processing capacity of the sales support staff of the service provider.

The parameter 'perceived service value' is defined as value in terms of time, efficiency, and safety of the service perceived by the customer through the marine transportation service. 'Service satisfaction' refers to overall satisfaction with the service provided by the marine transportation company. Finally, the dependent variable, transaction continuity, is defined as the intention to continue transactions with the company providing marine transportation services, and the intention of continuing a future-oriented relationship.

These variables were measured on a 5-point likert scale for the surveys. Three items were created for each of the five factors of 'service provision area', 'corporate image', 'price competitiveness', 'service expertise', and 'sales support' based on Panayides and Wiedmer (2011), Thai (2008), Wibowo and Deng (2012), Collins (1984), Frankel (1992), Kinard and Capella (2006), Surprenant and Solomon (1998), and Vesanen (2007), forming a total of 15 items. The parameter of perceived service value consists of three items: 'time', 'efficiency', and 'stability', based on Gwinner et al. (1998), Lee et al. (2010). Finally, service satisfaction, the dependent variable, consists of two items based on Chane et al. (2011) and Kuo et al. (2009), and transaction continuity consists of three items based on Komiak and Benbasat (2006), Morgan and Hunt (1994). Based on an exploratory factor analysis, one item each of corporate image and sales support were rejected, and two items of corporate image and sales support were analyzed.

Table 1: Variable Definitions and Measurement Items

\begin{tabular}{|c|c|c|c|}
\hline Factors & Operation Definition & Items & References \\
\hline Service Provision Area & $\begin{array}{l}\text { Regional factors including place of shipment, unloading ports, } \\
\text { destinations, etc. provided by the marine transportation company to } \\
\text { the customers }\end{array}$ & 3 & $\begin{array}{l}\text { Panayides \& Wiedmer (2011) } \\
\text { Thai (2008) }\end{array}$ \\
\hline Price Competitiveness & $\begin{array}{l}\text { Factors of price benefits and relative freight levels for services and } \\
\text { accurate freight proposals }\end{array}$ & 3 & $\begin{array}{l}\text { Collison (1984) } \\
\text { Frankel (1992) }\end{array}$ \\
\hline Sales Support & $\begin{array}{l}\text { Factors such as the knowledge level, information power, and work } \\
\text { processing capacity of the sales support staff of the service provider }\end{array}$ & 3 & $\begin{array}{c}\text { Surprenant \& Solomon (1987) } \\
\text { Vesanen (2007) }\end{array}$ \\
\hline Perceived Service Value & $\begin{array}{l}\text { Value in terms of time, efficiency, and safety of the service perceived } \\
\text { by the customer through the marine transportation service }\end{array}$ & 3 & $\begin{array}{l}\text { Gwinner et al.(1998) } \\
\text { Lee et al. (2010) }\end{array}$ \\
\hline Service Satisfaction & $\begin{array}{l}\text { Overall satisfaction with the service provided by the marine } \\
\text { transportation company }\end{array}$ & 2 & $\begin{array}{l}\text { Chane et al. (2011) } \\
\text { Kuo et al. (2009) }\end{array}$ \\
\hline
\end{tabular}

The survey was conducted for persons linked to shipping and port-related fields, IT and other port logistics service companies, and marine transportation services for companies including SCM manufacturing and trade and freight forwarders / NVOCC. An online survey was accordingly conducted focusing on related persons in marine transportation logistics and import and export companies in the Seoul metropolitan region and Gyeongnam region. The survey was conducted over 77 days from March 20 to June 5, 2019. A total of 281 surveys were collected, of which 68 were excluded for insincere answers. In all, 213 surveys were analyzed. Using SPSS 24.0, demographics and descriptive statistics and exploratory factor analyses were performed. For the path analysis of the hypotheses, AMOS 25.0 was used to perform confirmatory factor analysis, model verification, and path analysis based on the structural equation modelling analysis.

\section{Results}

\subsection{Demographics of the Respondents}

This study surveyed related persons in the marine transportation logistics service industry. The participants comprised $52 \%$ females and $48 \%$ males, with $18 \%$ under the age of $30,33 \%$ in their $30 \mathrm{~s}, 38 \%$ in their 40 s, and $11 \%$ aged 50 and above; thus, participants in their 40 s formed the largest group. In terms of work experience, $20 \%$ had less than 5 years, $32 \%$ had 5-10 years, 35\% had 10-20 years, and $13 \%$ had 20 years or more; thus, participants with 10-20 years of work 
experience formed the largest group. In terms of job position, $35 \%$ had the rank of staff, $37 \%$ of manager, $19 \%$ of director, and $9 \%$ of executive. Thus, participants with the position of staff to manager comprised a high proportion (Table 2).

Table 2: Demographics of Survey Participants

\begin{tabular}{|c|c|c|c|}
\hline \multicolumn{1}{|c|}{} & Category & Frequency & Ratio \\
\hline \multirow{4}{*}{ Gender } & Female & 111 & $52 \%$ \\
\cline { 2 - 4 } & Male & 102 & $48 \%$ \\
\cline { 2 - 4 } Age range & Total & 213 & $100 \%$ \\
\cline { 2 - 4 } & $0-30$ years of age & 38 & $18 \%$ \\
\cline { 2 - 4 } & $30-39$ years of age & 70 & $33 \%$ \\
\cline { 2 - 4 } & $40-49$ years of age & 82 & $38 \%$ \\
\cline { 2 - 4 } & 50 years of age & 23 & $11 \%$ \\
\hline \multirow{4}{*}{ Experience } & Total & 213 & $100 \%$ \\
\cline { 2 - 4 } & Less than 5 year & 43 & $20 \%$ \\
\cline { 2 - 4 } & $5-10$ years & 68 & $32 \%$ \\
\cline { 2 - 4 } & More than 20 years & 27 & $35 \%$ \\
\cline { 2 - 4 } & Total & 213 & $13 \%$ \\
\hline \multirow{4}{*}{ Job Position } & Executive & 19 & $90 \%$ \\
\cline { 2 - 4 } & Director & 40 & $19 \%$ \\
\cline { 2 - 4 } & Manager & 79 & $37 \%$ \\
\cline { 2 - 4 } & Staff & 75 & $35 \%$ \\
\cline { 2 - 4 } & Total & 213 & $100 \%$ \\
\hline
\end{tabular}

\subsection{Analysis Results of Reliability and Validity}

As seen in Table 3, both the reliability of the measurement model and the analysis of convergent validity showed good results. To analyze reliability and validity of the structural equation measurement model, the internal consistency reliability was obtained when the composite reliability index was 0.7 or more (Anderson \& Gerbing, 1988). Convergent validity is evaluated by factor loading, Cronbach's $\alpha$, and the composite reliability index. When factor loading is 0.5 or more and Cronbach's $\alpha$ is 0.7 or more and statistically significant, convergent validity can be obtained (Gefen et al., 2000). In accordance with these criteria, all factor loadings were good at 0.693 to 0.896 , all above 0.5 . Internal reliability was significant at 0.782 to 0.866 . The $\mathrm{t}$ value was 6.5 or more, indicating statistical significance. The average variance extracted (AVE) ranged from 0.546 to 0.710 , and Cronbach's $\alpha$ ranged from 0.776 to 0.865 , confirming convergent validity.

Table 3: Results of Reliability and Convergent Validity Test

\begin{tabular}{|c|c|c|c|c|c|c|c|}
\hline Variables & $\begin{array}{c}\text { Measurement } \\
\text { variables }\end{array}$ & $\begin{array}{c}\text { Standardized } \\
\text { Regression } \\
\text { Weights }\end{array}$ & $\begin{array}{l}\text { Standard } \\
\text { error }\end{array}$ & $t$ value & CR & AVE & Cronbach's a \\
\hline \multirow{2}{*}{$\begin{array}{c}\text { Service Provision Area } \\
\text { (SPA) }\end{array}$} & I_svc1 & 0.773 & - & - & \multirow{2}{*}{0.844} & \multirow{2}{*}{0.644} & \multirow{2}{*}{0.844} \\
\hline & I_svc3 & 0.804 & 0.097 & $11.256^{\star \star \star}$ & & & \\
\hline \multirow{2}{*}{$\begin{array}{l}\text { Corporate Image } \\
\text { (CI) }\end{array}$} & I_img2 & 0.759 & - & - & \multirow{2}{*}{0.815} & \multirow{2}{*}{0.689} & \multirow{2}{*}{0.808} \\
\hline & I_img3 & 0.896 & 0.167 & $6.536^{* * *}$ & & & \\
\hline $\begin{array}{l}\text { Price Competitiveness } \\
\text { (PC) }\end{array}$ & I_comp3 & 0.704 & 0.126 & $8.599^{* * *}$ & 0.782 & 0.564 & 0.776 \\
\hline \multirow{3}{*}{$\begin{array}{c}\text { Service Expertise } \\
\text { (SE) }\end{array}$} & I_tec1 & 0.784 & - & - & \multirow{3}{*}{0.866} & \multirow{3}{*}{0.683} & \multirow{3}{*}{0.865} \\
\hline & I_tec2 & 0.853 & 0.085 & $12.892^{* * *}$ & & & \\
\hline & I_tec3 & 0.841 & 0.083 & $12.724^{* * *}$ & & & \\
\hline $\begin{array}{l}\text { Sales Support } \\
\text { (SS) }\end{array}$ & I_sup2 & 0.842 & - & - & 0.814 & 0.687 & 0.812 \\
\hline \multirow{2}{*}{$\begin{array}{c}\text { Service Satisfaction } \\
\text { (SSa) }\end{array}$} & Sat1 & 0.766 & - & - & \multirow{2}{*}{0.829} & \multirow{2}{*}{0.710} & \multirow{2}{*}{0.818} \\
\hline & Sat2 & 0.913 & 0.151 & $9.072^{* \star *}$ & & & \\
\hline \multirow{3}{*}{$\begin{array}{l}\text { Transaction Continuity } \\
\text { (TC) }\end{array}$} & Tra1 & 0.861 & - & - & \multirow{3}{*}{0.855} & \multirow{3}{*}{0.633} & \multirow{3}{*}{0.855} \\
\hline & Tra2 & 0.799 & 0.072 & $12.746^{* * *}$ & & & \\
\hline & Tra3 & 0.782 & 0.079 & $12.447^{\star * \star}$ & & & \\
\hline
\end{tabular}

Note: ${ }^{*} p<0.05,{ }^{* *} p<0.01,{ }^{* * *} p<0.001$

For correlation analysis, if the square root of the AVE obtained between each latent variable is greater than the correlation coefficient of each latent variable, then discriminant validity between each latent variable can be obtained (Bae et al. 2019). Based on these criteria, this study analyzed the AVE and correlation coefficients between latent variables. As seen in Table 4, the square root of the AVE of each latent variable is larger than the correlation coefficients between latent variables, confirming discriminant validity. 
Table 4: Correlation Matrix and AVE

\begin{tabular}{|c|c|c|c|c|c|c|c|c|c|}
\hline Category & AVE & SPA & $\mathrm{Cl}$ & PC & SE & SS & $\mathbf{S Q}$ & SSa & TC \\
\hline SPA & 0.644 & 0.803 & & & & & & & \\
\hline $\mathrm{Cl}$ & 0.689 & $0.330^{* *}$ & 0.83 & & & & & & \\
\hline PC & 0.546 & $0.287^{\star *}$ & 0.044 & 0.739 & & & & & \\
\hline SE & 0.683 & $0.494^{\star *}$ & $0.316^{\star \star *}$ & $0.456^{\star \star \star}$ & 0.827 & & & & \\
\hline SS & 0.687 & $0.533^{\star \star *}$ & $0.365^{\star \star \star}$ & $0.465^{\star \star \star}$ & $0.702^{\star \star \star}$ & 0.829 & & & \\
\hline PSV & 0.642 & $0.224^{* *}$ & $0.186^{*}$ & $0.508^{\star \star \star}$ & $0.555^{\star \star \star}$ & $0.553^{\star \star \star}$ & 0.801 & & \\
\hline SSa & 0.71 & -0.008 & $0.184^{*}$ & $0.169^{*}$ & 0.078 & $0.175^{\star}$ & 0.117 & 0.843 & \\
\hline TC & 0.663 & -0.043 & $0.167^{*}$ & $0.322^{\star * \star}$ & 0.028 & $0.170^{*}$ & $0.283^{\star \star \star}$ & $0.621^{* * *}$ & 0.814 \\
\hline
\end{tabular}

Note: ${ }^{*} p<0.05,{ }^{\star \star} p<0.01,{ }^{\star \star *} p<0.001 /$ The square root of AVE is shown in bold letters.

\subsection{Analysis Results of Structural Model}

As seen in Table 5, based on goodness of fit analysis of the structural model, $\mathrm{t}$ variable is larger than the correlation of freedom, at 1.632. The goodness-of-fit-index (GFI) and normal fit index (NFI) were 0.892 and 0.882 , slightly below 0.9. However, root mean square residual (RMS) was 0.033 , adjusted goodness-of-fit-index (AGFI) was 0.855 , and root mean square error of approximation (RMSEA) was 0.055; thus, most goodness-of-fit values were excellent, indicating that the model fit was significant. CFI, which is not affected by the sample but expresses the explanatory power of the model, was 0.95 , and TLI, which determines the explanatory power of the structural model, was 0.939 , indicating that the basic model is very fit.

Table 5: Model Fit Indices for the Structural Models

\begin{tabular}{|c|c|c|c|c|c|c|c|c|c|}
\hline Model & $\mathbf{X}^{2}(\mathbf{d f})$ & $\begin{array}{l}\mathbf{X}^{2} / \text { degrees } \\
\text { of freedom }\end{array}$ & RMR & GFI & AGFI & NFI & TLI & CFI & RMSEA \\
\hline Original Model & 280.698 & 1.632 & 0.033 & 0.892 & 0.855 & 0.882 & 0.939 & 0.95 & 0.055 \\
\hline
\end{tabular}

Based on the hypothesis testing through the structural equation model path analysis, one of the seven hypotheses were rejected, as presented in Table 6 . Among transportation service use selection factors of marine transportation companies, service provision area showed a relatively positive effect on perceived service value of 2.021 ( $p<0.05$ ). However, corporate image (0.048) did not affect the perceived service value, while price competitiveness (3.266 $(p<0.01))$, service expertise $(2.581 \quad(p<0.05))$, and sales support $(2.46(\mathrm{p}<0.05))$ showed an effect. The perceived service value was $2.172(\mathrm{p}<0.05)$, showing a positive effect on service satisfaction, and service satisfaction was 7.779 (p $<0.001$ ), showing a positive effect on transaction continuity.

Table 6: Results of Hypothesis Test

\begin{tabular}{|c|c|c|c|c|}
\hline Hypothesis (path) & $\begin{array}{c}\text { Standardized } \\
\text { Regression Weights }\end{array}$ & t value & Support $(\mathrm{Y} / \mathrm{N})$ & $\mathbf{R}^{2}$ \\
\hline Service Provision Area $\rightarrow$ Perceived Service Value & 0.174 & $2.021^{*}$ & $\mathrm{Y}$ & \multirow{5}{*}{0.440} \\
\hline Corporate Image $\rightarrow$ Perceived Service Value & 0.033 & 0.448 & $\mathrm{~N}$ & \\
\hline Price Competitiveness $\rightarrow$ Perceived Service Value & 0.287 & $3.266^{* *}$ & $\mathrm{Y}$ & \\
\hline Service Expertise $\rightarrow$ Perceived Service Value & 0.286 & $2.581^{*}$ & $\mathrm{Y}$ & \\
\hline Sales Support $\rightarrow$ Perceived Service Value & 0.303 & $2.460^{*}$ & $\mathrm{Y}$ & \\
\hline Perceived Service Value $\rightarrow$ Service Satisfaction & 0.174 & $2.172^{*}$ & $\mathrm{Y}$ & 0.030 \\
\hline Service Satisfaction $\rightarrow$ Transaction Continuity & 0.636 & $7.779^{\star \star \star}$ & $\mathrm{Y}$ & 0.405 \\
\hline
\end{tabular}

Note: ${ }^{\star} p<0.05,{ }^{\star \star} p<0.01,{ }^{\star \star \star *} p<0.001$

Thus, as seen in Figure 2, service provision area, price competitiveness, service expertise, and sales support were shown to generally affect service satisfaction, though they also affected perceived service value. However, this study confirmed that the image of the marine transportation service provider itself does not directly affect perceived service value to customers.

\section{Conclusion}

Through the results of this study, as factors that determine the quality of services provided by marine transportation companies, service provision area, price competitiveness, service expertise, and sales support were found to have an effect. In particular, price competitiveness and service expertise were confirmed to be more important. Price competitiveness based on service expertise is the deciding factor for customers selecting a marine transportation company. Price competitiveness, the factor found to be the most important, demonstrates the reality that marine transportation competition is growing in intensity worldwide. However, unlike existing studies (Tse \& Wilton, 1988; Pavlou, 2007), this study found that corporate image, which refers to the reliability and service level that customers consider when selecting a marine transportation company, does not directly affect perceived service value of customers. 


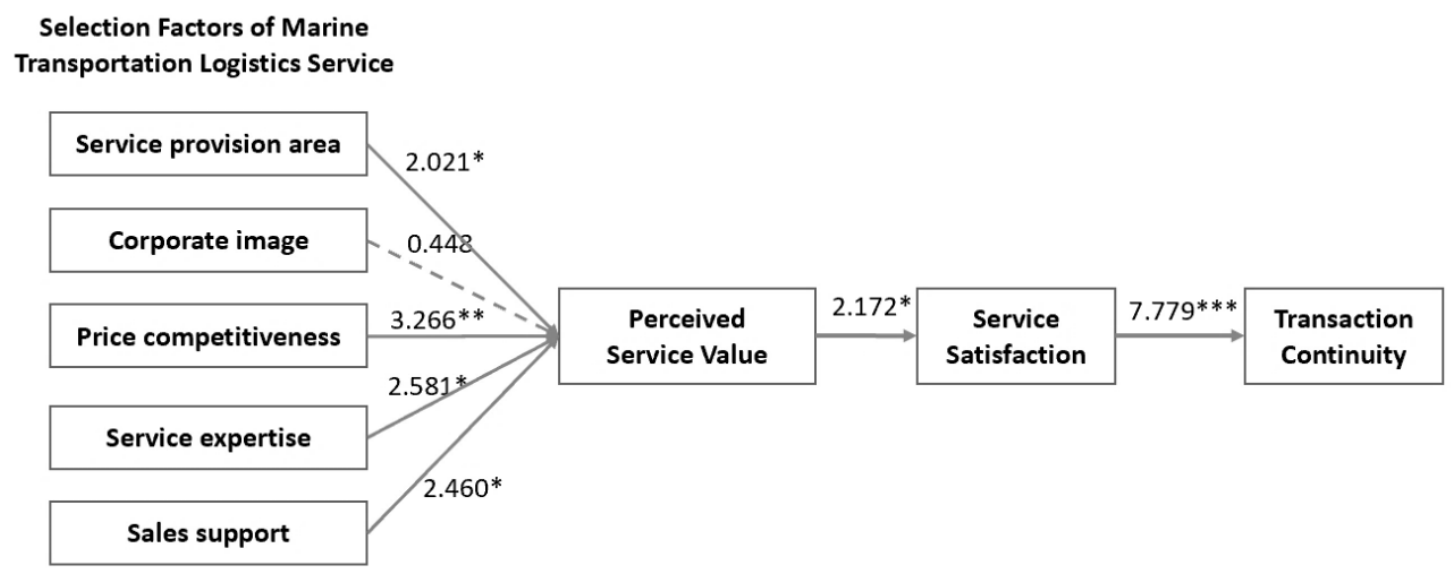

Figure 2: Analysis Result Model

As services of marine transportation companies are performed within company-to-company interactions, this result can be attributed to customers placing more importance on service factors that can more reliably drive transaction success (price competitiveness and service expertise), rather than emphasizing corporate image, which is not expressed through clear numbers or indicators. Accordingly, this study can present the following implications. First, while numerous major service factors for marine transportation services have been discussed over a long period of time, the factors considered as important competitive factors of actual marine transportation companies within the marine transportation market environment, which has changed rapidly since the 1990s were examined. From this perspective, even if both the time period and business environment change, as argued by Thai (2008) and Basir et al. (2015) price competitiveness was found to be the most important selection factor of marine transportation company services. However, unlike previous studies that argued that regional factors were important (Collinson, 1984; Yang et al., 2009), service expertise and sales support were found to have a greater impact on the perceived service value and satisfaction of customers. This result shows the growing need for expert services owing to changes in the technical environment, as well as the fact that the satisfaction for marine transportation services can be improved when combined with sales support capacity that can consider the sales or business situation of the client.

Second, in contrast to general service companies, the services provided by marine transportation companies are not easy to modify in the short term; moreover, the service orientation according to B2B characteristics is different from that of the general service industry. As such, marine transportation companies must provide intensive customer differentiation or customer-tailored services through market segmentation to pinpoint the target markets and differentiate the service quality required. In particular, considering the small number of major global companies in the industry, differentiated service strategies for each company will lead to differentiation strategies of the companies, thereby improving market competitiveness. Considerations for service differentiation strategies can thus be presented in the marine transportation market based on sales support tailored to B2B service through market segmentation.

Third, despite the fact that marine transportation companies are service companies, they are greatly affected by policies and regulations and have a long-term, regional trade relationship with the country. From this perspective, these companies have shown the inability to adopt a corporate mindset and strategies that consider service changes to meet market trends. However, the present transportation industry is diversifying, and regional, price, and time constraints of marine transportation services are rapidly declining. In consideration of these trends, marine transportation companies should also consider exploring new customer-oriented services and improving service quality through service innovation and an improved mindset. In general, it may be necessary to benchmark cases of service process innovations from various service companies and apply these cases to marine transportation services, and through this, explore corporate strategies for improving expertise to promote innovation through integrated transportation services that can be connected with marine transportation.

Despite the significance of this study, it has two limitations. First, there is a limitation due to generalization of research results that targeted workers of Korean marine transportation companies. Therefore, considering the global market of the marine transportation industry through surveys of representative global marine transportation companies from a variety of countries, it is necessary to derive macro and generalized research results on marine transportation service selection factors and quality. Second, the marine transportation service use selection factors of this study consisted of service provision area, corporate image, price competitiveness, service expertise, and sales support; 
however, this variable configuration is limited in that it was based on previous studies. With the rapid development of IT technologies and changes in the marine transportation environment through the emergence of mega carriers and the expansion of ships, the marine transportation industry and market are experiencing rapid fluctuations, accompanied by the creation of new innovative service factors in marine transportation logistics services as well. Therefore, research must be considered that derives new service selection factors in the actual marine transportation industry through qualitative research and uses this to present a greater variety of variables influencing service quality.

\section{References}

Aaker, D., \& Day, G. S. (1986). The perils of high-growth markets. Strategic Management Journal, 7(5), 409-421.

Ahn, K. H., Kim, M. S., \& Kim, B. I. (2008). The study of the effect of container terminal service quality on customer satisfaction and loyalty: The moderating effect of the company size and port location. Korea Business Review, 37(3), 417-442.

Anderson, J. C., \& Gerbing, D. W. (1988). Structural equation modeling in practice: A review and recommended two-step approach. America Psychology Association, 103(1), 411-423.

Back, I. H., \& Kwon, O. J. (2012). An introduction to maritime affairs. Seoul: Hae-In Publisher.

Bae, J. T., Kim, B. Y., \& Oh, S. H. (2019). The effects of purchase intention of oriental medicine cosmetics on selection and brand asset attributes. Journal of Distribution Sciences, 17(1), 73-87.

Basir, M., Modding, B., Kamase J., \& Hasan, S. (2015). Effect of service quality, orientation services and pricing on loyalty and customer satisfaction in marine transportation services. International Journal of Humanities and Social Science Invention, 4(6), 1-06.

Bolton, R. N., \& Drew, J. H. (1991). A multistage model of customers' assessments of service quality and value. Journal of Consumer Research, 17(4), 375-384.

Cha, S. S., \& Seo, B. K. (2019). The effect of brand trust of home meal replacement on repurchasing in online shopping. The East Asian Journal of Business Management, 9(3). 21-26.

Chellappa, R. K., \& Sin, R. G. (2005). Personalization versus privacy, an empirical examination of the online consumer's dilemma. Information Technology \& Management, 6(2-3), 182-202.

Chane, S., Fathian, M., \& Gholamian, M. R. (2011). Full relationship among e-satisfaction, e-trust, e-service quality and e-loyalty: The case of Ira E-banking. Journal of Theoretical and Applied Information Technology, 33(1), 2011, 1-6.

Chiu, C. M., Hsu, M. H., Lai, H., \& Chang, C. M. (2012). Re-examining the influence of trust on online repeat purchase intention: The moderating role of habit and its antecedents. Decision Support System, 53(4), 835-845.

Collinson, F. M. (1984). Market segments for marine liner service. Transportation Journal, 24(2), 40-54.

Cronin, J. J., Brady, M. K., \& Hult, G. T. (2000). Assessing the effects of quality, value, customer satisfaction on consumer behavioral intentions in service environments. Journal of Retailing, 76(2), 193-218.

Culnan, M. J., \& Bies, R. J. (2003). Consumer privacy, balancing economic \& justice considerations. Journal of Social Issues, 59(2), 323-342.

Desarbo, W. S., Jedidi, K., \& Sinha, I. (2001). Customer value analysis in a heterogeneous market. Strategic Management Journal, 22(9), 845-857.

Dick, A. S., \& Basu, K. (1994). Customer loyalty: Toward an integrated conceptual framework. Journal of the Academy of Marketing Science, 22(2), 99-113.

Drewry Maritime Research. (2018). 1Q drewry maritime research, NY:USA.

Durvasula, S., Lysonski, S., \& Mehta, S. C. (2000). Business-to-business marketing service recovery and customer satisfaction issues with ocean shipping lines. European Journal of Marketing, 34(3), 433-452.

Dwyer, F. R., \& Oh, S. (1987). Output sector munificence effects on the internal political economy of marketing channels. Journal of Marketing Research, 24(4), 347358.

Frankel, E. G. (1992). Hierarchical logic in shipping policy and decision-making. Maritime Policy and Management, 19(3), 211-221.

Ganesh, J., Armold, M. J., \& Reynolds, K. E. (2000). Understanding the customer base of service providers: An examination of the differences between switchers and stayers. Journal of Marketing, 64(3), 65-87.

Gundlach, G. T., Achrol, R. S., \& Mentzer, J. T. (1995). The structure of commitment in exchange. Journal of Marketing, 59(1), 78-92.

Gwinner, K. P., Gremler, D. D., \& Bitner, M. J. (1998). Relational benefits in services industries, the customer's perspective. Journal of the Academy of Marketing Science, 26(2), 101-114.

Hwang, K. Y., \& Goo, J. S. (2015). The roles of market orientation and service capability in entrepreneurial orientation-performance linkage: Evidence from international shipping firms. Korea Trade Review, 31(1), 81-105.

Ju, Y. H. (2007). A study of perceived value's effect on satisfaction and loyalty: An application to overseas golf travelers. Korea Tourism Research Association, 21(2), 325-337.

Julian, G. W. (1999). The impact of employee performance cues on guest loyalty perceived value and service quality. The Service Industries Journal, 19(3), 97-118.

Kim, D. Y., Yang, C. H., \& Kim, Y. J. (2009). The study of customer satisfaction with the port authority system: Focus on container terminal in Busan port. Journal of Korea Port Economic Association, 25(4), 229-254. 
Kim, H. D. (2016). An empirical study on the effects of pilot service quality on the shipping companies satisfaction and recommendation intention. Journal of Industrial Economics and Business, 29(6), 2749-2764.

Kim, K. I., Shin, H. W., \& Lee, S. W. (2009). An empirical study on the influence of shipping companies' service quality on customer satisfaction and loyalty. Journal of Korea Port Economic Association, 25(1), 223-248.

Kim S. Y., \& Joo, H. Y. (2008). Empirical study of structural relationship among port logistics service quality, port reputation and customer loyalty of liner ships. Korea Trade Review, 33(3), 1-30.

Kinard, B. R., \& Capella, M. L. (2006). Relationship marketing, the influence of consumer involvement on perceived service benefits, Journal of Services Marketing, 20(6), 359-368.

Kollat, D. T., Engel, J. F., \& Blackwell, R. D. (1970). Current problems in consumer behavior research, Journal of Marketing Research, 7(3), 327-332.

Komiak, S. Y., \& Benbasat, I. (2006) The effects of personalization \& familiarity on trust \& adoption of recommendation agents. MIS Quarterly, 30(4), 941-960.

Korea Maritime Institute. (2018). 2019 Maritime forecast report, Seoul: Korea.

Kuo, Y., Wu, C., \& Deng, W. (2009). The relationships among service quality, perceived value, customer satisfaction, and post-purchase intention in mobile valueadded services. Computers in Human Behavior, 25(1), 887-896.

Lai, K. H. (2004). Service capability and performance of logistics service providers. Transportation Research Part E: Logistics and Transportation Review, 40(5), 385-399.

Lee, H. G. (2014). A study on the satisfaction analysis of information service for port logistics. Journal of Korea Port Economic Association, 30(1), 57-71.

Lee, S. P., Shin, H. W., \& Choi, Y. R. (2010). A study on the effects of internal marketing on service quality and customer satisfaction in shipping companies. Journal of Korea Port Economic Association, 26(4), 122-146.

Morgan, R. M., \& Hunt, S. D. (1994). The commitmenttrust theory of relationship marketing. Journal of Marketing, 58(3), 20-38.

Panayides, P. M., \& Wiedmer, R. (2011). Strategic alliances in container liner shipping, Research in Transportation Economics, 32(1), 25-38.

Pavlou, P. A., Liang, H., \& Xue, Y.(2007), Understanding \& mitigating uncertainty in online exchange relationships: A principal agent perspective. MIS Quarterly, 31(1), 105-136.

Pearson, R. (1980). Containerline performance and service quality. U.K.: University of Liverpool, Marine Transport Center.

Peter, J. P., \& Olson, J. C. (1994). Understanding consumer behavior. Boston, MA: Irwin.

Rahman, A. M. (2018). Voluntary insurance for ensuring risk-free on-the-go banking services in market competition: A proposal for bangladesh. Journal of Asian Finance, Economics and Business, 5(1), 17-27.

Reichheld, F. F. (1993). Loyalty-based management. Harvard Business Review, 71(3/4), 64-73.

Shin, C. S., Hwang, G. S., Lee, H. W., \& Cho, S. R. (2015). The impact of Korean franchise coffee shop service quality and atmosphere on customer satisfaction and loyalty. The East Asian Journal of Business Management, 5(4), 47-57.

Shirley A. H., Strasser, S., Hopkins, W. E., \& Foster, J. R. (1993). Service quality gaps in the transportation industry: An empirical investigation. Journal of Business Logistics, 14(1), 222-237.

Sun, Y., Wang, N., Shen, X. L., \& Zhang, J. X. (2015). Location information disclosure in location-based social network services, privacy calculus, benefit structure, \& gender differences. Computers in Human Behavior, 52(1), 278-292.

Surprenant, C. F., \& Solomon, M. R. (1987). Predictability $\&$ personalization in the service encounter. Journal of Marketing, 51(2), 86-96.

Sweeney, J. C., \& Soutar, G. N. (2001). Consumer perceived value: the development of a multiple item scale. Journal of Retailing, 77(2), 203-220.

Tabash, M. I., Albugami, M. A., Salim M., \& Akhtar, A. (2019). Service quality dimensions of E-retailing of Islamic banks and its impact on customer satisfaction: An empirical investigation of kingdom of Saudi Arabia. Journal of Asian Finance, Economics and Business, 6(3), 225-234.

Tan, K. C., \& Wisner, J. D. (2000). A framework for quality improvement in the transportation industry. Quality Management Journal, 1(8), 9-22.

Taylor, S. A., \& Baker, T. L. (1994). An assessment of the relationship between service quality and satisfaction in the formation of consumer's purchase intention. Journal of Retailing, 2(1), 163-178.

Thai, V. V. (2008). Service quality in maritime transport: Conceptual model and empirical evidence. Asia Pacific Journal of Marketing and Logistics, 20(4), 493-518.

Tse, D. K., \& Wilton, P. C. (1988). Models of consumer satisfaction formation: An extension. Journal of Marketing Research, 25(2), 204-212.

Turel, O., \& Serenko, A. (2006). Satisfaction with mobile services in Canada: An empirical investigation. Telecommunications Policy, 30(5), 314-331.

Vesanen, J. (2007). What is personalization? A conceptual framework. European Journal of Marketing, 41(5/6), 409-418.

Wibowo, S., \& Deng, H. (2012). Intelligent decision support for effectively evaluating and selecting ships under uncertainty in marine transportation. Expert Systems with Applications, 39(8), 6911-6920.

Woodruff, R. B. (1997). Customer value: The next source for competitive advantage. Journal of the Academy of Marketing Science, 5(2), 139-153. 
Yang, C. C., Marlow, P. B., \& Lu, C. S. (2009). Assessing resources, logistics service capabilities, innovation capabilities and the performance of container shipping services in Taiwan. International Journal of Production
Economics, 122(1), 4-20.

Zeithaml, V. (1988). Consumer perceptions of price, quality and value: A means-end model and synthesis of evidence. Journal of Marketing, 52(3), 2-22. 